\title{
Review
}

\section{A political companion to Frederick Douglass}

\author{
Neil Roberts (Ed.) \\ Lexington, University of Kentucky Press, 2018, xi+476pp., \\ ISBN: 978-0813175621
}

Contemporary Political Theory (2020) 19, S121-S125. https://doi.org/10.1057/s41296018-00306-8; published online 2 January 2019

In a 1970 letter written to liberate Angela Davis and to preface her published lectures on liberation and Frederick Douglass, her UCLA colleagues cautioned that 'it was perhaps inevitable that Professor Davis should become a symbol for conflicting groups and causes. But it is well to remember that behind the symbol lies the human being whose thoughts are recorded here and that when she stands trial, not only a human cause but also a human life will be tried' (pp. 108-109).

A similar concern animates A Political Companion to Frederick Douglass, an edited volume that includes Davis's lectures alongside a variety of new and previously published work. As editor Neil Roberts acknowledges in the introduction, efforts to canonize Douglass risk sacrificing 'the prime content and intellectual impulses' that motivated his politics and philosophy (p. 3). How do we elevate Douglass as political theorist without eliding the many experiences and influences that ground his complex thinking? Roberts offers two related challenges that inspire this book as they have past scholarship: first, we must confront both the formal variety of Douglass's works-ranging from life writing to speeches, journalism, letters and photographs_as well as their uneven recognition in scholarship. Even Douglass's popular autobiographies were long relegated to an inferior literary status like that assigned to slave narrative, women's writings, and other genres. That scholars' eventual appreciation for those genres helped inaugurate Douglass into the pantheon of American thinkers reveals a second challenge: that we must conceive Douglass as a global thinker and actor, particularly in recognition of his relationship with Haiti.

Motivated by these challenges, Roberts has placed fourteen pieces across four thematic parts that champion Douglass's contributions as political theorist. The sequence and selection of these works are the book's two greatest strengths. Douglass knew the political power of storytelling, and so Roberts has wisely compiled these works with a clear narrative. An excerpt from Paul Gilroy's Black Atlantic introduces readers to the high stakes of this scholarship: that Douglass's life and literature do not merely demand that we include black politics in our

(C) 2019 Springer Nature Limited. 1470-8914 Contemporary Political Theory Vol. 19, S2, S121-S125 
appraisals of modernity, but that we rethink our inherited categories and traditions around the imbrications of slavery and the Enlightenment (p. 26). Lest readers be overwhelmed by Gilroy's grand narrative, the following selection by Bernard Boxill offers a closer, textual reading of Douglass and his pivotal fight with Edward Covey, 'the Negro Breaker' (Douglass, 1994, p. 258). The Political Companion's first section thus provides readers with a variety of methodological perspectives on oppression and freedom, with additional writings by Margaret Kohn, Angela Davis, and Robert Gooding-Williams further limning the contours of liberation and what the latter calls Douglass's 'plantation politics' (p. 141).

The book's following three parts mostly maintain the high stakes and story established by Gilroy and Boxill, each contributor portraying Douglass not merely as a unique political theorist, but one whose analysis expands general concerns in the discipline. Here we see the book's second great strength: with minor exceptions, the contributions written or revised for the Political Companion are on par with the selections previously published. This is a rare accomplishment, and similar edited volumes often avoid the risk of uneven chapters by selecting solely new or old work.

Both strengths are pronounced in the book's second section. There Jack Turner looks to Douglass's post-Reconstruction thought to outline his method of political judgment: on Turner's account, Douglass advocates judgment that involves intensive attention to particularity... without assimilating those particulars into preexisting categories that may not adequately capture their uniqueness,' while also introducing 'new principles of interpretation and evaluation' (p. 204). Douglass's attention to the mediating influence of race upon our political outlooks and the contested legacy of the Civil War and slavery carry profound relevance to contemporary issues. Though Turner compares Douglass on the Civil Rights Cases to the recent Shelby County v. Holder, we could also benefit from such a balance of situated and principled critique in today's efforts to bear witness against antiblack violence or voter suppression (pp. 224-226).

Ange-Marie Hancock Alfaro's 'Black Masculinity Achieves Nothing without Restorative Care' is another exemplary case of new work that weds careful scrutiny to contemporary significance. With exception to Shatema Threadcraft's recent Intimate Justice (2016), political theorists have done little with Douglass's complex depictions of masculinity across his autobiographical works and his popular 'SelfMade Men' address. Hancock Alfaro's intersectional exploration focuses not on Douglass's endorsement of women's rights or black manhood but the interdependence he forged in relationships with black male friends (pp. 236-237). Such analysis may not redeem him as the radical feminist we need now, but it is an important illumination if we are to think with Douglass today.

S122 (c) 2019 Springer Nature Limited. 1470-8914 Contemporary Political Theory Vol. 19, S2, S121-S125 
The second half of the volume weaves a compelling narrative that threads Douglass's political thinking from the abstract to the practical. Nicholas Buccola, Peter C. Myers, and Vincent Lloyd round out a surprisingly complementary account of Douglass on human nature and law. Adopting philosophical, historical, and affective orientations, the three present Douglass as a sophisticated observer of human behavior and society, who was challenged daily by America's contradictions. For example, Myers looks to the understudied Life and Times of Frederick Douglass to understand how its author balanced faith in human progress with the serried setbacks of an unjust society, while Lloyd portrays Douglass's letter to his former master Thomas Auld as evoking shared humanity both rational and affective (pp. 299-300, 314-316).

With Anne Norton's essay the book pivots to resistance and Douglass's reimagining of race-conscious citizenship. That the volume's final contributions emphasize distinct and often contradictory sides of Douglass leaves readers with myriad ways by which we might invoke Douglass in contemporary democracy. Compare Herbert Storing's individualist 'statesman' Douglass to Jason Frank's disruptive Douglass, whose Fourth of July address summons an unauthorized demos 'who could themselves retrospectively authorize such a claim' (pp. 347, 377). Nick Bromell concludes the book with a similar nod to productive contradictions: that 'in Douglass's view democratic citizenship presents citizens with several dilemmas that can never be resolved ... Citizens of a democracy must somehow hold these contradictory obligations in tension with each other' (p. 421). On this the book ends with an implicit return to that inaugurating dilemma so critical to Douglass's work: the tension between his lives and the practical and principled ideas he forged from them.

Overall, students and scholars new to Douglass will find the Political Companion a wonderful review of his most influential ideas, and an impressive summary of what scholarly work has been done and where new readers might continue the story. The book's strengths are testament not simply to Roberts's editorial oversight but to the flourishing of political theory scholarship penned over past decades. It is common throughout the volume to see contributors spar with and support their fellows, letting readers eavesdrop on the many debates that motivate contemporary conversation.

Yet the intimacy of this conversation reveals the book's few shortcomings, most of which likely reflect our flaws as political theorists and not the volume itself. Those familiar with Douglass scholarship know that his pivotal fight with Covey is among the richest but perhaps most wrung-out references for contemporary readers. The first section of A Political Companion is particularly representative of this focus. Though the book's selections eventually guide readers away from that well-

(c) 2019 Springer Nature Limited. 1470-8914 Contemporary Political Theory Vol. 19, S2, S121-S125 S123 
trodden territory, an unfortunate consequence of redundant reflections on Covey is that other compelling areas of Douglass's thought are left unexplored. The dramatized mutiny of Douglass's novella The Heroic Slave, his provocative 'Is It Right and Wise to Kill a Kidnapper?', his relationship with John Brown-all of these feature complex and nuanced depictions of violence and resistance that are relatively untouched in the book.

Related to this disciplinary narrowness is that those readers who overlook the book's thorough footnotes and bibliography will miss the significant scholarship on Douglass among historians, legal and literature scholars, much of which predates political theory's interest and that-in some cases-has moved on to consider unconventional yet crucial elements of his political thinking. Other than Boxill's inclusion, there is little acknowledgment of the 1980s and 1990s scholarship that politicized Douglass's oeuvre like that of William Andrew, Robert Cover, James Olney, Eric Sundquist, John Stauffer, Robert Levine, and more. Their work needn't be reproduced here, yet it is strange to hear their contributions so infrequently voiced.

The final shortcoming is one that Roberts himself acknowledges in the introduction, yet that disappears in the book's chapters: the overwhelming focus of scholarship on Douglass's Americanness. Both Juliet Hooker's Theorizing Race in the Americas (2017) and Roberts's own Freedom as Marronage (2015) are essential examples of the work that has pushed beyond this 'unfortunate pattern' (p. 6). No matter the reason why these or similar works were left out of the volumeand no matter the robust bibliography-the result is a collection that excludes not only Douglass's diplomatic work in Haiti, but his abolitionist tour in Britain, his critiques of the American Colonization Society and his later travels through Europe and Africa.

Both Douglass and Davis knew that liberation required not only political theory and action but shared solidarity across perspectives and positions. Emancipation would build from experience to cause, never losing sight of those complex and manifold lives that sought freedom. Long before that 1970 letter of support, Douglass, too, realized in writing My Bondage and My Freedom that 'not only is slavery on trial, but unfortunately, the enslaved people are also on trial' (1994, p. 106). We are fortunate to find in A Political Companion to Frederick Douglass a jury selected among those best fit to think with Douglass.

\section{References}

Douglass, F. (1994) My bondage and my freedom. In: Autobiographies. New York, NY: Library of America, pp. 103-452.

Hooker, J. (2017) Theorizing Race in the Americas: Douglass, Sarmiento, Du Bois, and Vasconcelos. Oxford: Oxford University Press.

S124 (c) 2019 Springer Nature Limited. 1470-8914 Contemporary Political Theory Vol. 19, S2, S121-S125 
Roberts, N. (2015) Freedom as Marronage. Chicago: The University of Chicago Press.

Threadcraft, S. (2016) Intimate Justice: The Black Female Body and the Body Politic. New York: Oxford University Press.

Publisher's Note Springer Nature remains neutral with regard to jurisdictional claims in published maps and institutional affiliations.

Nolan Bennett

Georgetown University, Washington, DC 20057, USA

nolan.bennett@georgetown.edu

(C) 2019 Springer Nature Limited. 1470-8914 Contemporary Political Theory Vol. 19, S2, S121-S125 S125 